THURSDAY, AUGUST II, 1870

\section{SCIENCE SCHOOLS AND MUSEUMS IN} $A M E R I C A$

$A$ T the present time when we are, as it were, taking A stock of our Scientific Institutions, an account of the various schools and colleges in the United States, in which Science is made a chief, if not the chief subject, may be welcome to our readers. A paper in the Canadian Naturalist, by Prof. Dawson-the result of the Professor's travels through the States, in order to determine by personal visits the practical working of the American Science Schools, and to use the experience so obtained, in the founding of a Canadian School of Science at Montreal-has been largely used.

It was for similar reasons that Prof. Agassiz visited the various museums of the Old World, in order to determine what errors he should avoid, and what precedents he should follow, in founding the magnificent Museum at Cambridge, U.S.

Referring to the various institutions in the various States, we will follow the footsteps of Prof. Dawson, adding whatever has been changed or improved since his visit.

In New York, Science has for some time past been at a very low ebb. Unlike London or Manchester, that busy mercantile community has no time to spend on such apparently trifling matters as the propagation of scientific knowledge, and the acquisition of materials for scientific investigation. The only School of Science in New York is Columbia College; an old-fashioned brick building, in a quaint, old-fashioned square, formerly outside the town, now, by the rapid increase of building, quite enclosed and surrounded. The College-buildings form three sides of a quadrangle, and are long, narrow rooms lighted by windows in the sides. Three rooms are used as laboratories for practical analysis, qualitative and quantitative. Another room is the furnace-room, for assaying purposes; another is used for purposes of drawing, and there are numerous classrooms and lecture-rooms, but all sadly out of proportion to the size of the town. Two rooms are set apart, one for the mineralogical, the other for the geological and palreontological collections. Among the latter the private cabinet of Prof. Newberry, especially rich in remains from the Carboniferous strata, is the most prominent feature.

The staff of professors, lecturers, and assistants, numbers eighteen in all; and the lectures, practical and theoretical, are purely scientific, embracing mineralogy, metallurgy, chemistry, botany, mechanics, physics, geology and palæontology, assaying, and drawing.

The full course for students is three years, at the end of which they are duly qualified for practical mining work, mineral surveying, and practical chemistry. They have to pass an entrance examination in algebra, geometry, and trigonometry, and at the end of their course most of them attain the degree of "Engineer of Mines," or "Bachelor of Philosophy." The number of students in the last account was from II 2 to 120 . An important feature of the course is that students are expected in the vacation to visit mines and metallurgical and chemical establishments, and to report on these, and also to make illustrative collections; while, during the session, short excursions are made to the machine shops and the metallurgical and chemical establishments in or near the city.

The practical value of such a course of training cannot be too highly appreciated; it is an example which many of our science schools and colleges would do well to follow. In justice, however, to one of the chief of these in England, it should be mentioned that the engineering and chemical classes in Owens College, Manchester, are in the habit of being taken by the respective professors to the leading scientific and chemical works near Manchester.

Besides Columbia College, New York is now in a fair way soon to possess a very fine public museum. In the beginning of 1869 a bill was carried in the House of Congress to establish in New York a museum, under Government control, similar to the British Museum. This museum is called "The American Museum of Natural History," and it published its first report a little time ago. The fine collection of the Prince of Neuwied, formed chiefly in the Brazils and South America, has been purchased, and communications have been sent to all the United States consuls throughout the world to aid the museum by the collecting and purchasing of valuable natural history specimens in their several localities. We cannot leave the State of New York without noticing how the liberal founder of the Comell University has made provision for practical and theoretical instruction in natural science. Laboratories, museums, herbariums, libraries of scientific works, have been either presented or bought; and by the scheme by which the students can work out the expenses of their education by their skilled labour, it is now possible for the very poorest artisan or mechanic in America to obtain as valuable a scientific education as any given anywhere in the world.

Proceeding from New York to New Haven, we find here a very important and very fine school of science. The Sheffield Scientific School is a modern outgrowth of the University of Yale College, and was first established in 1847 as a small undertaking, conducted by the elder Silliman, chiefly as a school for applied chemistry and scientific agriculture. In I 860 Mr. Sheffield, a wealthy citizen of New Haven, gave it a building and apparatus valued at 50,000 dollars, supplementing this by a grant of 50,000 dollars to found chairs of engineering, metallurgy, and chemistry. In 1863 it was further enlarged by grants of land from the State of Connecticut in aid of scientific education. It also participates in the benefit which Yale College derives from Mr. Peabody's Museum and his magnificent endowment of 150,000 dollars. The Sheffield School contains some fine natural history collections, one of the most valuable of which is one of Economic Geology, admirably arranged, and which shows the immense mineral wealth of America to great advantage.

The buildings of the school are finer and better arranged than those of Columbia College, and its educational scope is wider. There are six distinct courses of scientific instruction open to the students :-

I. Chemistry and mineralogy.

2. Engineering and mechanics.

3. Mining and metallurgy.

4. Agriculture.

5. Natural history and geology.

6. A select scientific and literary course. 
The class-rooms and laboratories are exiremely well adapted and arranged; there are small cabinets of specimens of great assistance to the professors in delivering their lectures. It also possesses a fine equatorial telescope, made by Clark, having an object-glass with an aperture of nine inches. For this there is a properly constructed tower, furnished with all the necessary instruments for astronomical observations.

The staff of professors, lecturers, \&c., numbers twentythree, and the number of students is now about 150 . Amongst the distinguished men holding appointments here, the names of Dana, Silliman, and Marsh are of European renown.

In Philadelphia we find valuable scientific collections belonging to the Academy of Science, an old and still very vigorous scientific establishment, though sadly wanting more room for its collections. Amongst the treasures of these collections there are several that merit particular notice.

Professor Hawkins has just set up in the museum the skeleton of the Hadrosaurus of the New Jersey Greensand, one of the most gigantic of the immense mesozoic reptiles. Besides this extremely valuable skeleton and other remains, there are portions of the skeleton of a gigantic carnivorous reptile of the same age, with formidable cutting teeth, similar to those of the megalosatrus, and, like it, possessing hooked claws, some of which must have been ten inches long.

Belonging to the Philadelphia Academy of Sciences is a fine scientific library, but both it and the collections suffer from want of space. The museun also contains a fine and very complete collection of American skulls, which Messrs. Morton, Wilson, and Meigs have so elaborately worked out. At Philadelphia two valuable works on palæontology have been undertaken. One of these just published was reviewed in NATURE for Jure 16, and is an extremely valuable monograph on "The Fossil Mammals of America," by Prof. Leidy. The other work is an equally valuable one, being a monograph on the "Fossil Reptiles of America," by Prof. Cope.

Proceeding from Philadelphia to "the queenly city," Baltimore, we find there an Academy and a band of zealous naturalists, as Tyson, Morris, and Dalrymple. The Peabody Institute here was founded by Mr. Peabody, who was a resident in this city for some time, and who presented to the town the sum of 100,000 dollars for these objects, viz.: (l) to found an extensive library; (2) to provide for the delivery of lectures in science and art; to found (3) an academy of music, and (4) a gallery of art.

The building of the institute was in 1868 being rapidly proceeded with, and is probably now finished. There was then no museum, but the library had already become extremely valuable.

In Washington is located the splendid Smithsonian Institution, of world-wide fame, founded for "the increase and the diffusion of knowledge amongst men," now under the direction of Prof. Henry, the able president of the American Academy of Sciences, and who is now in this country. The chief work hitherto done by the Smithsonian Institution has been in the subjects of geology and natural history, and it already possesses extremely valuable collections, carefully and systematically arranged under the able supervision of Prof. Baird. This institution sets a glorious example to other and much older museums in their treatment of those anxious and willing to make use of the accumulated treasures. Their collections are open to the inspection of any naturalist from any part of the world; who, in some cases, are accommodated with rooms for their work, as well as access to the specimens. Under Prof. Henry's personal superintendence a fine collection of American antiquities is in process of formation, and the number and importance of these objects of early warfare and art make the museum extremely valuable and instructive.

It was in Washington that President Lincoln was 50 basely assassinated. The building where the event took place, formerly Ford's theatre, has been converted into a museum of a character it is believed perfectly unique. This, the Army Medical Museum, contains a series of excellently mounted preparations of great professional interest, remarkable chiefly for its profuse exhibition of the effects of shot and shell, and other implements of war on the human frame. The materials for this museum were chiefly collected during the American Civil War. It may well be said that the Americans are a wonderful people; there are few other nations which would have been capable of so utilising the results of a protracted internecine war as to make them available in after years towards the advancement of medical science and the alleviation of human pain.

In addition to the purely medical collection, this museum also contains a fine and well-arranged collection of skulls of the various aboriginal American tribes, with a few Mexican and Peruvian. There is also a fine collection of skulls in the Smithsonian Institution.

Before concluding this paper it is necessary to mention two separate munificent gifts, by which the late Mr. Peabody did so much to promote the cause of science in America. The Peabody donation to Yale College has been previously alluded to. One result of this is that Yale College, which was formerly devoted to other subjects, has recently made great progress in science, and bids fair to become one of the leading scientific institutions in America. It still lacks, however, funds towards founding more scientific professorships. Besides this donation, Mr. Peabody in 1867 left I40,000 dollars "for the promotion among the inhabitants of my native county (Essex County, Massachusetts) of the study and knowledge of the natural and physical sciences and their application to the useful arts."

From this gift started the Peabody-Academy of Sciences in Salem, Massachusetts, which was inaugurated August I8, I 869. The objects of the foundation are still kept in view by the formation of a museum, which, besides a general collection, shall embrace a complete collection of local specimens from the whole county, and shall keep up and augment the museum of East Indian antiquities collected by the East Indian marine societies, and by the formation of a series of lectures on science, to be yearly delivered.

And, lastly, the nature of the valuable museum which Professor Agassiz is collecting at Harvard College, Cambridge, aided by Government grants and private subscriptions, will have been sufficiently learnt from the article on the Harvard Museum, which appeared in NATURE for June 23 . 